\title{
Pengaruh harga kualitas produk dan distribusi terhadap keputusan pembelian
}

\author{
Heru Sucianto Tjia ${ }^{1}$, Suharno $^{2}$, M.Amin Kadafi ${ }^{3}$ \\ Fakultas Ekonomi dan Bisnis Universitas Mulawarman, Samarinda. \\ ${ }^{1}$ Email: heru.sucianto.tjia@mhs.feb.unmul.ac.id \\ ${ }^{2}$ Email: Suharno@feb.unmul.ac.id \\ ${ }^{3}$ Email: m.amin.kadafi@feb.unmul.ac.id
}

\begin{abstract}
Abstrak
Tujuan dari penelitian ini adalah untuk mengetahui pengaruh harga, kualitas produk, dan distribusi berpengaruh secara signifikan terhadap keputusan pembelian di PT Duta Kreasi Tehnik Samarinda. Adapun alat yang digunakan dalam penelitian ini adalah analisis regresi berganda. Hasil dari penelitian ini menunjukan bahwa pengaruh harga, kualitas produk dan distribusi berpengaruh secara parsial terhadap keputusan pembelian, dimana dalam uji $\mathrm{T}$ (parsial) mendapatkan hasil thitung $>$ ttabel.
\end{abstract}

Kata Kunci: Harga; kualitas produk; dan distribusi

\section{The effect of product quality and distribution prices on purchasing decisions}

\begin{abstract}
The purpose of this study is to determine the effect of price, product quality, and distribution significantly influence purchasing decisions in PT Duta Kreasi Tehnik Samarinda. The tools used in this study is multiple regression analysis. The results of this study indicate that the influence of price, product quality and distribution partially influence the purchase decision, where in the T test (partial) get the result tcount> ttable
\end{abstract}

Keywords: Price; product quality; and distribution 


\section{PENDAHULUAN}

PT Duta Kreasi Tehnik merupakan salah satu supplier spare part di Kota Samarinda dengan specialist produk hydraulic hose. Produk yang dijual merupakan hasil produksi beberapa perusahaan yang memiliki citra sangat baik (goodwill). Produk dengan kualitas terbaik yang memiliki keunggulan lebih tahan tekanan dibandingkan merk yang lainnya dan juga memiliki kelenturan dikarenakan matrial yang terbuat dari synthetic rubber sehingga lebih lentur dibandingkan dengan merk lain.

Kualitas produk yang dijual PT Duta Kreasi Tehnik telah teruji lebih dari 25 tahun dengan berbagai perusahaan yang ada di Samarinda. Tjiptono Fandy (2008: 95,103) Dasar pengambilan keputusan dapat dilihat melalui atribut produk yaitu unsur - unsur produk yang dipandang penting oleh konsumen dan dijadikan dasar pengambilan keputusan pembelian meliputi (merek, kemasan, jaminan, pelayanan). Harga akan cenderung menjelaskan kualitas produk barang tersebut. Unsur harga memainkan peran yang penting dalam menarik keputusan pembelian konsumen sehingga konsumen dapat memilih bukan hanya produk yang unggul tetapi harga juga bersaing, PT Duta Kreasi Tehnik tidak hanya memberikan produk yang berkualitas tetapi juga harga yang bersaing.

\section{Tinjauan Teoritis}

\section{Harga}

Menurut Lupiyoadi (2011: 61) Strategi penentuan harga (pricing) dipengaruhi sangat signifikan dalam pemberian value kepada konsumen dan mempengaruhi image produk, serta keputusan konsumen untuk membeli. Harga juga berhubungan dengan pendaptan dan turut mempengaruhi supply atau marketing channels.

Menurut Kotler (2002) dalam Doni Hariadi (2013) harga adalah jumlah uang yang dibebankan atau dikenakan atas sebuah produk atau jasa. Penentuan harga barang dan jasa memainkan peran stategik didalamnya banyak perusahaan sebagai konsekuensi deregulasi, kompetisi global yang intens dan peluang bagi perusahaan untuk memperkokoh posisi pasarnya.

Menurut Tjiptono (2012:151) "harga adalah satuan moneter atau ukuran lainnya (termasuk barang dan jasa lainnya) yang ditukarkan agar memperoleh hak kepemilikan atau penggunaan suatu barang atau jasa. Pengertian ini sejalan dengan konsep pertukaran (exchange) dalam pemasaran”.

Menurut Fure (2013:276), Indikator yang digunakan untuk mengukur harga antara lain :

a) Harga sesuai dengan manfaat

b) Persepsi harga dan manfaat

c) Harga barang terjangkau

d) Persaingan harga

\section{Kualitas Produk}

Menurut Gitosudarmo (2000:117) dalam Doni Hariadi (2013) produk merupakan segala sesuatu yang diharapkan dapat memenuhi kebutuhan manusia.

Menurut Kotler dan amstrong (2011:258): "product quality stands the ability of a product to perform its function. It is includes the product's overall durability, reliability, precision, ease of operation and repair, and other value attributes. Some of these attributes can be measured objectively. From a marketing point of view, however, quality should be measured in term of buyer's perception."

Dapat diartikan bahwa kualitas suatu produk adalah kemampuan yang bisa dinilai dari suatu produk didalam menjalankan fungsinya, yang merupakan suatu gabungan dari daya tahan, keandalan, ketetapan, kemudahan pemeliharaan serta atribut - atribut lainnya dari suatu produk. Dari segi pemasar kualitas harus diukur dari sudut pengelihatan dan tanggapan pembeli terhadap kualitas itu sendiri. Dalam hal ini selera pribadi sangat mempengaruhi. Oleh karena itu secara umum dalam mengelola kualitas produk, harus sesuai dengan kegunaan yang diharapkan.

Berbagai performa pengukuran suat produk menurut Kotler (2007:9), dimensi kualitas produk meliputi:

a) Kinerja (performance)

b) Keistimewaan tambahan (features)

c) Keandalan (reliability) 
d) Kesesuaian dengan spesifikasi (conformance to specifications)

e) Daya tahan (durability)

f) Estetika (asthethic)

\section{Distribusi}

Beberapa ahli banyak mengemukakan tentang pengertian dan pendapatnya, menurut Revanz (dalam Angipora, 2002:295) menyatakan bahwa saluran distribusi merupakan suatu jalur yang dilalui oleh arus barang-barang dari produsen ke perantara dan akhirnya sampai pada pemakai

Sedangkan menurut Walters (dalam Angipora, 2002:269) menyatakan bahwa saluran distribusi adalah sekelompok pedagang dan agen perusahaan yang mengkombinasikan antara pemindahan fisik dan nama dan suatu produk untuk menciptakan kegunaan pasar tertentu.

Kotler (dalam Angipora,2002:296) Saluran distribusi merupakan sebagai himpunan perusahaan dan perorangan yang mengambil alih hak atau membantu dalam mengalihkan hak atas barang atau jasa tersebut berpindah dari produsen ke konsumen.

Distribusi adalah ketersediaan produk dan kemudahan membeli produk di PT Duta Kreasi Tehnik Samarinda. Saluran distribusi dapat diukur dari beberapa indikator. Menurut Suharno (2015:21) saluran distribusi diukur berdasarkan:
a) Ketersediaan barang
b) Proses pemesanan
c) Kecepatan dalam pengiriman
d) Kemudahan dalam memperoleh produk

\section{Keputusan Pembelian}

Menurut Kotler dan Keler (2009:240) "Keputusan pembelian adalah keputusan konsumen mengenai preferensi atas merek-merek yang ada di dalam kumpulan pilihan".

Sedangkan menurut Kotler, Amstrong, (2008:227) " keputusan pembelian adalah keputusan pembeli tentang merek mana yang dibeli” Proses pembelian menurut Kotler, Keller 2009:184-192) Dalam proses pembelian yang spesifik terdiri dari urutan kejadian berikut:

Secara rinci tahap-tahap tersebut dapat diuraikan sebagai berikut:

a) Pengenalan masalah, Proses membeli diawali saat pembeli menyadari adanya masalah kebutuhan, pembeli menyadari terdapat perbedaan antara kondisi sesungguhnya dengan kondisi yang diinginkannya.

b) Pencarian informasi, Seorang konsumen yang mulai timbul minatnya akan terdorong untuk mencari informasi lebih banyak.

c) Kita dapat membedakan dua tingkat yaitu keadaan tingkat pencarian informasi yang sedangsedang saja yang disebut perhatian yang meningkat.

d) Umumnya jumlah aktivitas pencarian konsumen akan meningkat bersamaan dengan konsumen berpindah dari situasi pemecahan masalah yang terbatas ke pemecahan masalah yang esktensif.

Salah satu faktor kunci bagi pemasar adalah sumber-sumber informasi utama yang dipertimbangkan oleh konsumen dan pengruh relatif dari masing- masing sumber terhadap keputusankeputusan membeli.

Menurut Harmani (2008:41) dalam Iful anwar (2015) menyatakan bahwa keputusan pembelian merupakan proses pengintegrasian yang mengkombinasikan untuk mengevaluasi dua atau lebih perilaku alternative, dan memilih salah satu diantaranya. Indikator yang digunakan untuk mengukur keputusan pembelian konsumen antara lain:

a) Keputusan terhadap produk yang tersedia

b) Keputusan terhadap harga yang tersedia

c) Keputusan terhadap harga yang diberikan

d) Keputusan terhadap pelayanan yang diberikan 


\section{Variabel penelitian dan Definisi Oprasional}

Variabel penelitian adalah suatu atribut atau sifat atau nilai dari orang,objek atau kegiatan yang mempunyai variasi tertentu yang ditetapkan oleh peneliti untuk dipelajari dan ditarik kesimpulannya (Sugiyono, 2007)

Terdapat dua Variabel dalam penelitian ini, yaitu:

\section{1) Variabel Bebas (independent)}

Variabel bebas yaitu variabel yang dapat mempengaruhi atau menjadi penyebab bagi variabel lainnya. Pada penelitian ini variabel bebasnya yaitu:
a. Harga
b. Kualitas produk
c. Distribusi
d. Variabel Keputusan Pembelian (Y).

\section{Populasi dan Sampel}

Populasi adalah wilayah generalisasi yang terdiri dari objek atau subjek penelitian yang mempunyai kualitas dan karakteristik tertentu yang ditetapkan oleh peneliti untuk dipelajari dan kemudian ditarik kesimpulannya (Sugiyono, 2010:285)

Sampel pada penelitian ini yaitu sebagian orang yang menjadi anggota populasi dari penelitian.

Menurut Hair et al., (2010:172) penetapan sampel menggunakan rumus sebagi berikut :

Keterangan :

$$
\mathbf{n}=(15 \text { sampai dengan 20) } \times \mathbf{k}
$$

$$
\begin{array}{ll}
\mathrm{n} & =\text { Sampel ( Konsumen yang dijadikan responden) } \\
\mathrm{K} & =\text { Jumlah Variabel penelitian yang digunakan } \\
\text { 15 Sampai dengan } 20 & \text { = Jumlah observasi menurut pendapat Hair }
\end{array}
$$

\section{Jenis dan Sumber Data}

Adapun Jenis sumber data yang digunakan dalam penelitian ini adalah sebagai berikut:

a. Data Primer

b. Data Sekunder

\section{METODE}

a) Uji Validitas

Uji validitas digunakan untuk mengetahuai ketepatan suatu alat ukur dalam melakukan fungsi ukurnya.

b) Uji Reabilitas

Reabilitas menunjuk pada suatu pengertian bahwa sesuatu instrument cukup dapat dipercaya untuk digunakan sebagai alat pengumpulan data karena instrument tersebut sudah baik.

c) Uji T (Parsial)

Pengujian secara parsial digunakan untuk menguji apakah setiap koefisien regresi variabel bebas mempunyai pengaruh atau tidak terhadap variabel tidak bebas. Memperoleh hasil uji $t$ ini, maka digunakan rumus dari Rangkuti (2003:220) sebagi berikut:

$$
=\mathrm{b} / \mathrm{Sb}
$$

Dimana :

$b \quad=$ Parameter estimasi

$S b \quad=$ Standart eror Kriteria pengujiannya:

Ho:b1 $=0$, Artinya tidak terdapat pengaruh yang berarti antara variabel variabel bebas terhadap terikat Ha:b $1 \neq 0$, Artinya terdapat pengaruh yang berarti antara variabel variabel bebas terhadap terikat atau;

thitung > ttabel dengan signifikansi 0,05 maka ditolak dan Ha diterima, artinya signifikan thitung < ttabel dengan signifikansi 0,05 maka ditolak dan Ha ditolak, artinya tidak signifikan. 


\section{Indikator Signifikansi:}

a) Jika nilai probabilitas 0,05 lebih besar dari nilai probabilitas Sig atau $(0,05>\mathrm{Sig})$, maka H0 ditolak dan Ha diterima, artinya variabel $\mathrm{X} 1, \mathrm{X} 2, \mathrm{X} 3, \ldots \mathrm{Xn}$ seacara parsial berpengaruh signifikan terhadap variabel Y.

b) Jika nilai probabilitas 0,05 lebih kecil dari nilai probabilitas $\mathrm{Sig}$ atau $(0,05<\mathrm{Sig})$, maka $\mathrm{H} 0$ diterima dan Ha ditolak, artinya variabel $\mathrm{X} 1, \mathrm{X} 2, \mathrm{X} 3, \ldots \mathrm{Xn}$ seacara parsial tidak berpengaruh signifikan terhadap variabel $\mathrm{Y}$.

c) Agar lebih mempermudah dan mempercepat proses analisis ini, maka digunakan sistem komputerisasi dengan menggunakan program SPSS 22.

\section{HASIL DAN PEMBAHASAN}

Berdasarkan hasil perhitungan dan analisis data diatas, maka dapat dinyatakan persamaan regresi sebagai berikut :

$$
\mathrm{Y}=-0.120+0.094 \mathrm{X}_{1}+0.458 \mathrm{X}_{2}+0.217 \mathrm{X}_{3}
$$

Dari persamaan tersebut menunjukan bahwa variabel harga $\left(\mathrm{X}_{1}\right)$, kualitas produk $\left(\mathrm{X}_{2}\right)$, empati (X3), mempunyai pengaruh yang signifikan terhadap keputusan pembelian (Y), berarti jika variabel bebas yaitu harga, kualitas produk, dan distribusi mempunyai peningkatan maka akan berpengaruh terhadap keputusan pembelian dan apabila sebuah perubahan terjadi di dalam variabel harga, kualitas produk, dan distribusi maka akan berpengaruh dalam tingkat konsumen untuk membeli produk di PT. Duta Kreasi Tehnik cabang Samarinda.

Agar dapat mengetahui pengaruh variabel independent yaitu Harga (X1), kualitas produk (X2), dan distribusi (X3) maka dilakukan dengan Uji $\mathrm{F}$ melalui perhitungan statistic maka menunjukan Fhitung $=46,448$ dan Ftabel $=2,3538$ dengan tingkat signifikansi sebesar $0,00<0,05$. Dengan kata lain harga, kualitas produk, dan distribusi mempunyai pengaruh yang positif dan signifikan terhadap keputusan pembelian.

Untuk mengetahui pengaruh dari masing - masing variabel bebas (independent) $\left(\mathrm{X}_{1}, \mathrm{X}_{2}\right.$ dan

$\left.\mathrm{X}_{3}\right)$ terhadap variabel terikat (dependent) sebagai berikut:

1) Variabel harga

Harga sebagai komponen penting utama dengan tingkat sensitivitas cukup tinggi memberikan peranan penting dalam mempengaruhi keputusan pembelian yang dilakukan konsumen.

2) Kualitas Produk

Sebagai mana telah diungkapkan pada pendahuluan, bahwa produk yang di perdagangkan PT Duta Kreasi Tehnik merupakan hasil produksi dari Semperit Co Ltd di Austria yang telah terbukti kredibilitasnya sebagai produsen selang syntetic dan suku cadang.

3) Variabel Distribusi

Konsep distribusi yang dilakukan oleh PT Duta Kreasi Tekhnik adalah dengan melakukan pendekatan ke lokasi operasi perusahaan. Konsep ini tidak lantas membangun cabang diberbagai tempat namun lebih kepada upaya membangun komunikasi dan kerja sama dengan berbagai perusahaan.

\section{SIMPULAN}

1. Berdasarkan perhitungan statistik terbukti bahwa variabel bebas yang terdiri dari variabel harga,kualitas produk, dan distribusi berpengaruh terhadap keputusan pembelian PT Duta Kreasi Tehnik cabang Samarinda. Berdasarkan perhitungan juga terbukti bahwa terdapat pengaruh yang signifikan dari variabel bebas terhadap variabel terikat

2. Pada variabel bebas besarnya pengaruh tidak memiliki beda yang besar,hal ini menjelaskan bahwa variabel harga,kualitas produk, dan distribusi sama-sama berpengaruh terhadap keputusan pembelian PT Duta Kreasi Tehnik cabang Samarinda. 


\section{DAFTAR PUSTAKA}

Alma, Buchari. 2011. Manajemen Pemasaran dan Manajemen Jasa, Cetakan kesembilan, Alfabeta, Bandung.

Akbar, A. 2012. Analisis Pengaruh Citra Merek, Harga, dan Kualitas Produk terhadap Keputususan Pembelian Notebook Toshiba. Fakultas Ekonomika dan Bisnis Jurusan Manajemen Universitas Gunadarma, Jakarta.

Angipora, M.P. 2002. Dasar - Dasar Pemasaran, Edisi Kedua, PT. Raja Grafindo Persada , Jakarta

Arikunto, S. 2005. Manajemen Penelitian,Cetakan Ketujuh,PT. Rineka Cipta, Jakarta

Anwar, Iful dan Satrio Budhi. 2015. Pengaruh Harga dan Kualitas Produk terhadap Keputusasn Pembelian, Volume 4, Nomor 12.

Budiyono Haris dan Amirullah. 2004, Pengantar Manajemen . Penerbit Graha Ilmu, Yogyakarta

David, Downey, 2002, Manajemen Agribisnis, Buku keempat. Penerbit Airlangga, Jakarta

Fure, H. 2013. Lokasi, Keberagaman Produk, Harga dan Kualitas Pelayanan pengaruhnya Terhadap Minat Beli pada Pasar Tradisional Bersehati Calaca, Fakultas Ekonomi dan Bisnis, Universitas Sam Ratulangi, Manado. 